\title{
TANAM BUAH DALAM POT (TABULAMPOT) SEBAGAI PENGUATAN EKONOMI DAN SOSIAL MASYARAKAT DESA CALUK, DUSUN GUPIT, KECAMATAN SLAHUNG, PONOROGO.
}

\author{
Niswatul Hidayati \\ Fakultas Syariah, IAIN Ponorogo. \\ Email: niswa@iainponorogo.ac.id
}

\begin{abstract}
ABSTRAK
Ekonomi adalah salah satu faktor dan unsur yang sangat penting dalam pembangunan peradaban manusia. Jika kondisi ekonomi kuat dan sejabtera maka elemen-elemen yang lain dalam masyarakat akan ikut kuat dan kondusif. Dalam rangka pemberdayaan ekonomi itu pula pendampingan dilakukan melalui program tanam buah dalam pot atau tabulampot yang dipilih sebagai bentuk pengabdian kepada masyarakat desa Caluk. Kondisi geografis desa Caluk berupa tanah yang tandus menjadi aset sekaligus tantangan dalam pendampingan kali ini. Disisi yang lain, meskipun kondisi tanabnya tandus namun mayoritas masyarakat Caluk adalah petani. Maka, program tanam buah dalam pot menjadi pilihan karena sedikit membutubkan air serta lahan yang tidak luas. Pendekatan dalam pendampingan masyarakat ini menggunakan metode Asset Based Community - Driven Development (ABCD) dengan menggali aset sebagai kekuatan masyarakat desa Caluk. Pendampingan dilakukan mulai dari mencangkok sebagai bibit tanaman, membuat media tanaman, sampai tanaman berbuab dan memiliki nilai ekonomi sehingga bisa dijual.
\end{abstract}

Kata kunci: peningkatan ekonomi, tanam buah dalam pot, aset.

\begin{abstract}
Economy is one of important factor and elements in developing buman civilization. If the economy is stable and strong, then other element of life of the community will be strong and conducive. One of the way to develop the economy of a community is by giving them guidance or mentoring how to grow plant using a pot. The mentoring is chosen as the devotion form to the society especially in Caluk village. In one side, the majority of the lands in Caluk village are barren which is considered not only as a challenge but also as an asset. In another side, most of people in Caluk. village are farmer. Therefore, growing plant in a pot is a practical one because it does not need a vast area. This mentoring will be conducted by using ABCD (Asset Based Community - Driven Development) approach. This approach will stress on digging the asset of community as the main power. This mentoring will begin with grafting as a method to gain seed, then making the plant media, until the plant bare its fruit and ready to sell.
\end{abstract}

Keywords: economic development, growing plant in a pot, asset.

\section{PENDAHULUAN}

Perguruan tinggi memiliki tanggungjawab sosial untuk dapat berperan dalam pembangunan nasional dan peradaban manusia menuju lebih ke depannya. Hal ini 
telah tertera secara legal formal dalam Undang undang nomor 12 tahun 2012 tentang pendidikan tinggi. Jauh sebelum itu dan lebih mendasar dari semata-mata hanya untuk memenuhi aturan perundangan Negara, pendidikan secara normatif, filosofis dan historis hendaknya membawa perbaikan dan perubahan pada masyarakat. ${ }^{1}$

Ada dua landasan yang mendasari dilaksanakannya tanggung jawab sosial dari perguruan tinggi, yaitu normativ agama dan ilmu sosial. Dalam perspektif agama Islam jelas mengusung semangat mendorong kemajuan dan perbaikan keadaan manusia, meninggalkan ketidakadilan menuju keadilan. Aksi sosial merupakan bagian dari ajaran Islam, dimana IAIN Ponorogo sebagai salah satu agent Islam yang tranformatif. Adapun landasan dari ilmu sosial, Paulo freire mengatakan "education is not neutral", pendidikan itu tidak netral tapi harus berpihak, yakni berpihak pada mereka yang tertindas dan mendorong pada upaya-upaya perbaikan.

Perguruan tinggi sebagai pengemban amanah pendidikan mengusung mandat yang disebut dengan tridharma pendidikan. Secara sederhana maksudnya adalah misi dan mandat perguruan tinggi yakni mencakup tiga kewajiban atau aturan yang harus dijalankan. Yakni pengajaran, penelitian dan pengabdian. Pada dharma pengabdian berhubungan secara langsung dengan masyarakat, menyuarakan kewajiban pengabdian secara spesifik dan eksplisit. Bentuk pengabdian diwakili dengan kegiatan pengabdian baik dalam bentuk sporadis individual oleh dosen maupun secara kelembagaan oleh kampus. Di sinilah kegiatan pengabdian menemukan tempatnya dalam sejarah.

Terdapat tiga paradigma yang digunakan dalam pengabdian masyarakat. Paradigma ini merupakan kerangka umum pemikiran dan asumsi-asumsi yang mempengaruhi dan dipengaruhi oleh nilai-nilai dan perilaku masyarakat baik local atau global pada masanya. ${ }^{2}$ Paradigma pertama; Charity (bakti sosial atau sedekah). Asumsi dari pemikiran ini adalah bahwa kampus merupakan pihak yang punya sumber daya pengetahuan dan teknologi sehingga wajib untuk memberikan kepada masyarakat yang dianggap sebagai pihak yang tidak punya dan selalu dalam keadaan membutuhkan uluran tangan perguruan tinggi. Kegiatan- kegiatan model pengabdian ini seringkali bersifat sporadic dan berupa santunan makanan, pakaian, dan alat-alat rumah tangga.

1 Pedoman Kuliah Pengabdian Masyarakat (KPM) Pos pemberdayaan Keluarga (Posdaya) Berbasis Masjid, LPPM IAIN Ponorogo (2017), 31.

2 Ibid., 


\section{Indonesian Engagement Journal}

Vol. 2 No. 1 Juni 2021

Kedua; paradigma project (proyek). Asumsi dasar dalam paradigma ini adalah bahwa pengabdian harus dilakukan dengan cara yang terorganisir. Sehingga model pengabdian ini diawali dengan kajian masalah yang dihadapi oleh masyarakat, menentukan solusi, merencanakan tindakan, dan menerapkan rencana untuk mencapai tujuan yang ditetapkan. Pengabdian seperti ini seringkali mengabaikan peran masyarakat sebagai unsur yang paling berkepentingan dalam proyek karena mereka dianggap bukan sebagai ahli atau orang yang terlatih. Oleh sebab itu, masyarakat dinilai membutuhkan pelatihan-pelatihan ketrampilan beserta penguasaan teknologinya.

Ketiga; paradigma social change atau tranformasi sosial. yaitu paradigma yang meyakini nilai-nilai keadilan dan kearifan local. Pengabdian ini menitikberatkan pada proses pengembangan hubungan intra-masyarakat sebagai satu kesatuan warga yang setara dan dengan pemangku kepentingan lainnya secara proposional. Menciptakan lingkungan pembelajaran secara kolektif dan kolaboratif adalah bentuk dari kegiatan pengabdian ini. Masyarakat dipandang sebagai satu unit komunitas yang mempunyai kuasa dan kendali atas asset, sumber daya dan masalahnya sendiri. Selain itu, masyarkat dianggap punya sesuatu yaitu kekuatan dan kekuasaan yang seringkali kuranga tau tidak berkembang. Oleh sebab itu, kegiatan-kegiatan dalam paradigma ini bersifat empowering dan berkelanjutan dan menyertakan niali-nilai democratic governance untuk berbagi kekuasaan dengan adil dalam masyarakat. Fokus dari pengabdian ini terletak pada pemanfaatan dan pemeliharaan sumber daya masyarakat beserta penyediaan akses yang merata untuk semua lapisan masyarakat.

Ketiga paradigma di atas bisa dipahami sebagai satu kontinum, artinya satu sama lain tidak perlu dipertentangkan. Adakalanya satu paradigma dan model pengabdian masyarakat tepat untuk dipakai dalam konteks-konteks tertentu. hal yang terpenting dari masing-masing paradigma itu adalah integritas antara niat baik dan tindakan pengabdian yang sesuai dengan konteks dan bermuara pada terciptanya pola hubungan yang adil dan setara dari berbagai aspek, seperti gender, lingkungan, budaya, sosial, dan politik. Ketiga paradigma diatas mempunyai nilai spesifiknya masing-masing yang bisa digunakan dalam konteks yang berbeda yang berujung pada tujuan yang satu, membawa perbaikan kualitas kehidupan manusia yang bermartabat penuh dengan nilai-nilai keadilan sosial. 


\section{Indonesian Engagement Journal}

Vol. 2 No. 1 Juni 2021

Dengan demikian artikel ini hendak menerjemahkan paradigma pengabdian yang dilaksanakan di desa Caluk, Slahung, Ponorogo. Berawal dari pemetaan wilayah, komunitas, asosiasi, dan asset individu yang merupakan metode dan alat menemukenali asset. ${ }^{3}$ Untuk pemetaan wilayah dilakukan dengan penelusuran zona wilayah dusun Gupit, Caluk tersebut. Seperti lahan, tanah, tanaman, kepemilikan lahan dan lain sebagainya. Fakta yang didapatkan bahwa kebanyakan lahan pertanian di dusun Gupit bukan asli milik masyarakat Gupit, mereka hanya bekerja di lahan orang saja saat musim hujan. Kebanyakan di musim kemarau masyarakat dusun Gupit pergi bekerja merantau keluar kota. Masyarakat dusun Gupit tidak semua beragama Islam, ada yang beragama katholik, namun perbedaan agama tersebut tidak membuat tenggang rasa antar warga justru kerukunan antar warganya sangat erat dan juga sikap gotong royong antar warganya masih sangat tinggi. Hal ini juga merupakan asset yang dimiliki dusun Gupit selain asset yang bersifat fisik.

Berdasarkan pemetaan dan hasil evaluasi maka pendampingan yang ditawarkan oleh IAIN Ponorogo adalah sistem tanam dalam pot atau tabulampot dengan bibit hasil mencangkok dengan media tulus. Karena kebanyakan lahan pertanian di dusun Gupit bukan asli milik mereka, maka muncul inisiatif untuk memberikan pendampingan tabulampot tersebut dengan harapan setiap rumah milik warga di dusun Gupit memiliki tanaman buah demi keberlangsungan ketersediaan buah minimal untuk satu keluarga. Harapan lebih dari pendampingan ini agar dapat membantu perbaikan ekonomi warga Gupit dari buah yang dihasilkan secara mandiri.

\section{METODE}

Pengabdian Masyarakat ini mengangkat tema "Pemberdayaan Melalui Pengembangan Potensi untuk Mewujudkan Masyarakat Madani”, dengan menggunakan metode ABCD (Asset Based Community-driven Development), yaitu sebuah pendekatan dalam pengembangan masyarakat yang hanya berfokus pada asset lingkungan yang dimiliki oleh masyarakat itu sendiri. Kegiatan tersebut dilakukan oleh tim pengabdian masyarakat di desa Caluk kecamatan Slahung kabupaten Ponorogo. Daerah ini dipilih sebagai salah satu lokasi kegiatan pengabdian, dimana wilayah ini terletak di Ponorogo bagian Barat dan menjadi wilayah lintas menuju

3 Lembaga Penelitian dan Pengabdian kepada Masyarakat (LPPM) IAIN Ponorogo. (2019). Panduan KPM ABCD IAIN Ponorogo. Ponorogo: Lembaga Penelitian dan Pengabdian kepada Masyarakat (LPPM) IAIN Ponorogo, 58. 
kota Pacitan, yang penduduknya berprofesi sebagai petani. sedangkan mayoritas kaum mudanya bekerja ke luar negeri sebagai tenaga migran.

Kondisi ini cukup menarik dengan mengetahui kenyataan bahwa sumber daya yang potensial sebagai generasi penerus banyak yang harus meninggalkan desa. ${ }^{4}$ Adapun salah satu potensi atau asset yang dimiliki masyarakat desa Caluk adalah pekarangan yang cukup luas dan kemauan masyarakat untuk berwirausaha dengan memanfaatkan modal yang sudah ada di desa mereka. Maka kegiatan pendampingan yang tepat sangat dibutuhkan untuk menggali potensi yang mereka miliki. Yakni dengan mengadakan pendampingan wirausaha tanam buah dalam pot atau diistilahkan dengan Tabulampot.

Tahapan awal dalam metode ABCD adalah Inculturasi atau perkenalan. Tahap perkenalan di lakukan melalui proses komunikasi dengan masyarakat dengan bergabung bersama masyarakat dan menjadi bagian dari segala rutinitas yang melibatkan banyak orang pada masyarakat mitra. Tahapan ini bertujuan untuk memahami maksud atau tujuan kegiatan pengabdian, membangun kepercayaan masyarakat mitra serta memfasilitasi kelompok masyarakat lokal untuk mengembangkan komunitasnya. Informasi yang terkumpul pada tahapan ini berguna dalam perencanaan kegiatan dan pengembangan asset yang ada di dusun Gupit selanjutnya.

Tahap selanjutnya dalam proses penelitian pengabdian terdiri atas lima aksi yang harus dilakukan, yakni;

a. Discovery (menemukan)

Discovery adalah proses pengungkapan informasi melalui pendekatan partisipasi masyarakat sekitar. Pendekatan partisipastif yang telah diawali dari pencarian asset dikembangkan lebih lanjut dengan sharing bersama warga sekitar dan beberapa perangkat desa untuk megetahui potensi positif yang ada di lingkungan dusun Gupit. Potensi yang ada di masyarakat yang ada di desa caluk yaitu pertanian dengan megandalkan air hujan saja. Sehingga, petani hanya dapat mengolah sawah dan ladangnya hanya pada musim penghujan saja.

b. Dream (Impian)

4 Karlina, Eli, Muhammad Arif, dan Sodikin. (2017). "Pengaruh Bekerja di Luar Negeri terhadap Tingkat Ekonomi dan Perceraian,” Sosio Didaktika, Vol. 4, no. 1, 54-60. 


\section{Indonesian Engagement Journal}

Vol. 2 No. 1 Juni 2021

Masyarakat dusun Gupit memiliki potensi-potensi yang sebenarnya dapat dimanfaatkan. Impian yang diharapkan masyarakat diantaranya, adanya peningkatan kreatifitas masyarakat dalam mengolah Sumber Daya Alam yang ada di Dusun Gupit dan adanya peningkatan ekonomi masyarakat di Dusun Gupit. Diantara kesekian asset yang dimiliki masyarakat dipilihlah tanam buah dalam pot sebagai kegiatan untuk peningkatan ekonomi masyarakat dengan biaya yang murah.

c. Design (merancang)

Design merupakan proses untuk merancang apa yang perlu dikembangkan dalam memanfaatkan potensi yang sudah ada di komunitas. Dalam tahap merancang ini, dirumuskan pengembangan kegiatan, seperti: pelaksanaan pelatihan mengenai cara pembuatan tanam buah dalam pot sebagai bentuk inovasi pelaksanaan kewirausahaan dan pertanian.

d. Define (menentukan)

Define merupakan proses untuk memberikan kesempatan bagi masyarakat untuk mendefinisikan potensi dan kekuatan yang dimiliki. ${ }^{5}$ Masyarakat memiliki kesempatan untuk merefleksikan potensi dan memproyeksikan impian yang dicapai dengan mengembangkan potensi yang ada. Bagi warga dusun Gupit, salah satu potensi yang mereka miliki adalah bahwa mayoritas mereka menekuni bidang pertanian meskipun dengan kondisi lahan yang tandus. Maka, sangat tepat jika mereka melakukan inovasi menanam buah dengan sistem tabulampot (tanam buah dalam pot).

e. Destiny

Tahapan ini adalah langkah terakhir yakni melaksanakan program kegiatan yang sudah disepakati. Adapun strategi yang sudah dibuat, selanjutnya diimplementasikan dengan bentuk nyata kegiatan. Pelaksanaan kegiatan yang dilakukan tidak lain untuk memenuhi impian masyarakat untuk memanfaatkan sumber daya alam yang ada atau asset yang sudah tersedia, serta meningkatkan perekonomian warga. Yakni dengan melaksanakan tanam buah dalam pot atau tabulampot. Menyadari bahwa lahan persawahan hanya bisa ditanami ketika musim penghujan saja, maka dengan inovasi tabulampot masyarakat tetap bisa mendapatkan hasil dari asset yang sudah dimiliki, dengan memindahkan media dari lahan kerap

5 Pedoman Kuliah Pengabdian Masyarakat (KPM) Pos pemberdayaan Keluarga (Posdaya) Berbasis Masjid, 78. 
kering saat musim kemarau ke media pot sebagai media tanam. Buah yang dipanen nantinya dijual sehingga meningkatkan perekonomian masyarakat.

\section{ANALISIS DAN PEMBAHASAN}

Dusun Gupit, kecamatan Slahung adalah sebuah wilayah yang di sebelah selatan kabupaten Ponorogo. Kondisi di dusun ini sangat minim air ketika musim kemarau. Hal ini menyebabkan para petani di dusun Gupit ini menjadi berhenti dalam bercocok tanam dan melakukan kegiatannya di sawah / ladang. Akan tetapi warga Gupit ini tidak merasa putus asa akan hal ini, mereka menggantinya dengan tanaman kunyit dan singkong karena kedua tanaman itu bisa hidup tanpa banyak membutuhkan air, kunyit di olah menjadi rempah rempah tradisional dan di pasarkan melalui pasar khususnya di Pasar Slahung. Hasil olahan singkong ada yang di konsumsi pribadi dan ada yang di olah menjadi Gaplek, yaitu makanan khas di jawa yang terbuat dari singkong dan ditambah bumbu khas. warga menjual singkong baik yang berupa masih singkong apa adanya serta ada juga yang menjual dalam bentuk olahan demi memenuhi kebutuhan ekonomi sehari hari.

Terkait kondisi perekonomian masyarakat di Dusun Gupit, rata-rata masyarakatnya adalah seorang petani, peternak dan ada juga yang bekerja di luar negeri sebagai TKI (Tenaga Kerja Indoesia). Karena kondisi tanah yang kering dan susahnya pasokan air, para petani di dusun ini menanami lahannya dengan pohon singkong dan juga empon-empon (rempah-rempah). Singkong yang banyak di temui atau banyak di tanam di dusun ini adalah Ketela Pohon, sedangkan rempah-rempah yang banyak ditanam di dusun ini adalah Kunyit. Kedua jenis tanaman ini adalah tanaman yang tidak terlalu membutuhkan banyak air dalam perawatannya. Dan tergolong tanaman yang mudah perawatannya. Menurut salah seorang petani yang menanami ladangnya dengan empon-empon (kunyit), pada saat musim panen tiba mereka akan mengirimkan hasil panenannya kepada pengepul untuk kemudian di jual bersamaan dengan hasil dari petani lain ke pasar. Sedangkan untuk Ketela Pohon, kebanyakan dijadikan gaplek (bahan dasar nasi tiwul) kemudian baru di jual.

Program tanam buah dalam pot dipilih karena kegiatan ini efektif yang bertujuan untuk menggatikan cocok tanam pada musim kemarau. Tanaman yang digunakan adalah Jambu air, jambu biji dan Jambu biji merah, sebab tanaman ini juga tahan dengan air yang sedikit, cocok di tanam dalam musim kemarau karena buah ini 
tumbuh tidak kenal musim dan dapat terus hidup dengan air yang sedikit. Pendampingan ini merupakan salah satu solusi yang ditawarkan oleh IAIN Ponorogo untuk mengatasi keadaan lahan yang tidak bisa ditanami ketika musim kemarau. Sehingga masyarakat Gupit dalam musim kemarau pun bisa mendapatkan hasil dari penjualan buah-buahan hasil dari sistem tanam buah dalam pot.

Supaya tabulampot dapat efektif, pendampingan dilakukan langsung kepada para ibu-ibu PKK desa Gupit dan bahkan sekaligus para bapak-bapak juga mengikuti program tanam buah dalam pot ini. Kegiatan ini juga agar bertujuan menambah penghasilan masyarakat untuk kususnya pada musim kemarau, karena harga buah di pasaran selalu bagus dan untuk tanaman buah yang ditanam ini berbuah tidak mengenal musim. Jadi manfaat tanam buah dalam pot atau tabulampot ini sangat bermanfaat untuk mengatasi kekeringan dan membantu perekonomian serta asupan gizi bagi masyarakat desa Caluk sendiri.

Kondisi tanah di Gupit saat ini tergolong kering dan tandus terutama saat musim kemarau. Hal ini menyebabkan para petani tidak bisa menggarap sawah atau ladangnya karena jika datang musim kemarau menyebabkan minimnya pasokan air yang dibutuhkan oleh tanaman mereka. Seperti halnya daun-daun berguguran karena kekeringan, sungai-sungai yang mengalir di dusun Gupit ini juga mengering. Dengan latar belakang kondisi alam seperti itu, maka tanam buah dalam pot menjadi alternatif yang mampu memberdayakan ekonomi warga, terutama saat musim kemarau tetap ada yang bisa dipanen dan dijual.

Tanam buah dalam pot atau yang biasa disebut Tabulampot merupakan suatu inovasi baru dari kegiatan bercocok tanam. Karena tidak membutuhkan tempat yang luas, cukup tempat yang mendapatkan sinar matahari yang cukup. Tabulampot merupakan salah satu jenis bercocok tanam yang paling mudah,karena tidak membutuhkan banyak perawatan, cukup diberikan tulus atau pupuk dan air. Untuk pupuk diberikan setiap satu bulan sekali dan untuk air disiram sesuai dengan tingkat kekeringan dari tanah yang menjadi media menanam. Unsur-unsur yang dibutuhkan sebagai media menanam terdiri dari:
a. Tanah kering yang dihaluskan
b. Tulus (pupuk)
c. Sekam padi yang dibakar
d. Pecahan batu bata 


\section{Indonesian Engagement Journal}

Vol. 2 No. 1 Juni 2021

Untuk langkah yang pertama, campurkan tanah kering yang telah dihaluskan dengan sekam padi, selanjutnya masukkan pecahan babu bata pada lapisan paling bawah dalam pot, kemudian masukkan sedikit tanah untuk meratakan permukaan batu bata. Kemudian masukkan bibit tabulampot yang diikuti dengan memasukkan tanah yang telah dicampur dengan sekam padi. Dan untuk lapisan paling atas diberi pupuk yang diratakan.

Tujuan pengabdian dalam pendampingan pembuatan tanam buah atau tabulampot adalah untuk memfasilitasi dan memaksimalkan pengembangan asset yang dimiliki di Dusun Gupit sebagai berikut :

a. Masyarakat mampu mengolah asset yang dimiliki secara mandiri.

b. Masyarakat mampu mengembangkan asset yang dimiliki agar memiliki nilai penghasilan yang tinggi.

Pengabdian pada kegiatan pendampingan kali ini fokus pada pengembangan asset-asset yang ada di dusun Gupit. Karena tanah di daerah ini tergolong sangat tandus dan kering pada saat musim kemarau dan tidak bisa digunakan untuk bercocok tanam. Kesulitan bercocok tanam ini membuat masyarakat dusun Gupit yang mayoritas warganya adalah petani mengalami kesulitan perekonomian karena tidak memanen. Maka perlu inovasi baru agar pada saat tanah sedang kering dan tandus akibat kemarau panjang para petani tetap bisa memanfaatkan tanah untuk bercocok tanam. Tanaman buah yang dipilih dalam program tabulampot adalah buah jambu, jambu madu deli, dan jauhari. Sistem tabulampot ini dipilih karena tanah yang ada di Dusun Gupit ini sangat tandus dan kering disebabkan oleh musim kemarau. Sedangkan tabulampot dengan media pupuk kompos atau organik dapat menyimpan cadangan air yang cukup lama didalam pot dan membuat tanaman yang ada didalam pot akan tetap sejuk dan memilki cadangan air.

Selain itu, Tabulampot memiliki berbagai keunggulan diantaranya yaitu; ${ }^{6}$

a. area tanah yang dibutuhkan tidak terlalu luas;

b. menghasilkan buah-buahan yang minim pestisida;

c. mempercantik halaman rumah dan pekarangan disekitarnya;

d. masa berbuah dan berbunga dapat diatur sehingga produksi buah tidak tergantung musim;

6 https://paktanidigital.com/artikel/panduan-mudah-cangkok-jambu-biji-bagipemula/"Panduan Mudah Cangkok Jambu Biji Bagi Pemula" diakses pada tanggal 20 Maret 2020. 
Indonesian Engagement Journal

Vol. 2 No. 1 Juni 2021

e. pertumbuhan tanaman tidak merusak areal disekitarnya;

f. kebutuhan nutrisi tanaman dapat diperoleh secara maksimal;

g. pemberian pupuk dan penyiraman lebih terencana;

h. jika terserang hama atau penyakit penanggulangannya juga lebih mudah.

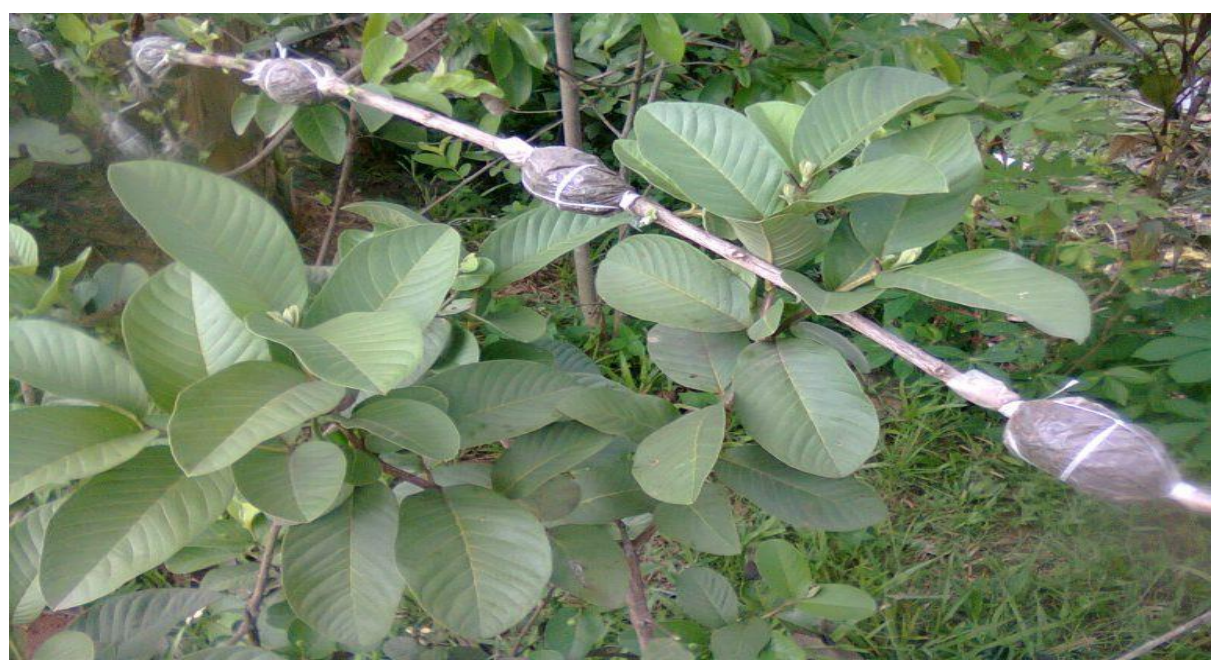

Gambar 1. Proses pencangkokan buah jambu biji merah.

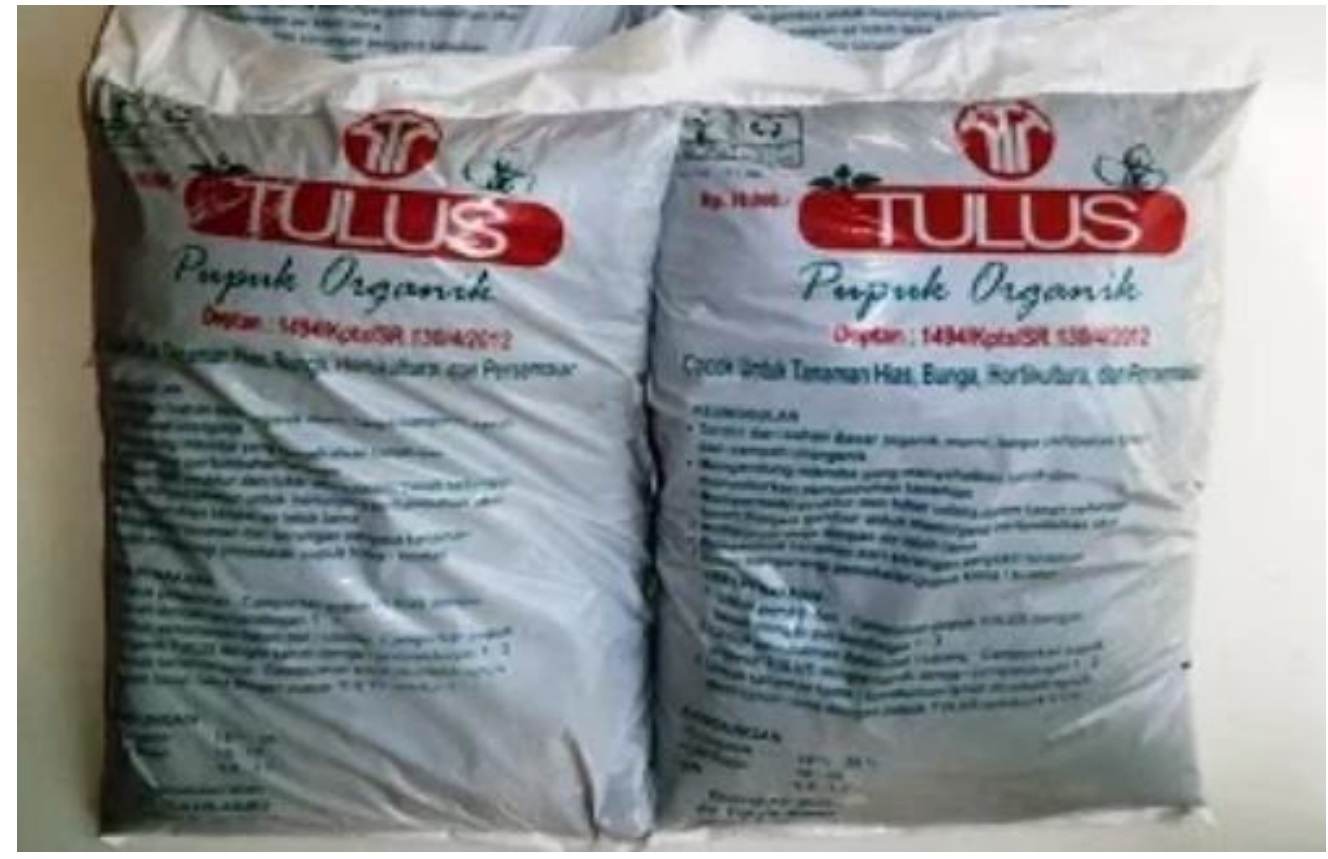

Gambar 2. Contoh pupuk oraganik yang bisa digunakan untuk mencangkok. 


\section{Indonesian Engagement Journal}

Vol. 2 No. 1 Juni 2021

Adapun cara menanam dan merawat tabulampot yakni, ${ }^{7}$

a. Mempersiapkan bibit tanaman. Bibit ini bisa dibeli seharga 9 ribu rupiah, atau bisa mencangkok sendiri dalam waktu kurang lebih dua bulan.

b. Mempersiapkan pot sebagai media tanam yang akan di tanami bibit buah jambu, misalnya atau hasil cangkokan.

c. Setelah pot tersedia, di isi dengan pecahan genteng dan ditambah serabut kelapa supaya air lebih stabil, tidak terlalu becek atau kering. Kemudian, memasukkan bibit tanaman buah jambu biji merah dan menguruknya dengan tanah yang sudah diracik dengan pupuk organic.

d. Setelah tanaman jambu biji merah sudah di tanam di dalam pot, Langkah selanjutnya yaitu penyiraman. Tanaman diletakkan di tempat terbuka dengan pencahayaan yang cukup. Untuk musim kemarau penyiraman bisa dilakukan cukup sekali setiap hari yakni pagi atau sore. Sedangkan saat musim hujan penyiraman dilakukan Ketika media tanam sudah kering.

e. Langkah selanjutnya adalah pemangkasan. Agar tanaman bisa berbuah dengan maksimal harus dilakukan pemangkasan. Yakni memangkas bagian cabang yang tidak terlalu baik pertumbuhannya supaya saat pemupukan nutrisi tidak termakan oleh cabang yang kurang baik tersebut.

f. Karena tabulampot memiliki persediaan nutrisi yang terbatas, maka harus dipupuk misalnya pupuk organik tulus. Pemupukan pertama dilakukan satu bulan setelah ditanam, dan selanjutnya bisa dipupuk dalam jangka waktu 2 sampai 3 bulan sekali. Untuk jenis pupuk disarankan menggunakan pupuk organik atau pupuk kandang. Jika terpaksa menggunakan pupuk kimia bisa dilakukan tetapi dengan dosis yang sedikit.

g. Tahap akhir adalah masa panen. Jambu biji merah tabulampot memiliki masa panen yang bervariasi tergantung pada cara perawatannya. Ada yang 8 bulan, namun ada juga yang 1,5 tahun baru bisa berbuah dan dipanen. Kisaran harga jambu biji merah Ketika dijual bisa mencapai 15,000 / kg. sedangkan harga satu sak pupuk hanya 5000 rupiah dan jika harus membeli bibit buah jambu biji merah hanya 9000 per bibit. Dengan hitungan tersebut maka secara ekonomi akan sangat menguntungkan sehingga mampu menopang ekonomi warga. Hal ini bisa

7 Panduan Lengkap Cara Menanam TABULAMPOT (Tanaman Buah Dalam Pot) yang RAJIN Berbuah"https://rumahtanaman.com/tabulampot-tanaman-buah-dalam-pot/ diakses pada tanggal 15 Maret 2021. 


\section{Indonesian Engagement Journal}

Vol. 2 No. 1 Juni 2021

mengurangi para warga supaya bertahan di desanya dengan wirausaha cocok tanam dan tidak perlu lagi menjadi buruh migran.

Tabulampot dengan media pupuk organik atau kompos hanya memerlukan perawatan dengan mengontrol tanah yang ada didalam pot masih basah atau sudah kering, biasanya tanah didalam pot ini hanya memerlukan siraman air 2 hari sekali atau 1 hari sekali pada saat pagi atau sore hari. Adapun bibit tanaman atau buah bisa didapatkan dengan cara mencangkok terlebih dahulu dengan media pupuk misalnya pupuk organik tulus.

Pendampingan tabulampot didukung penuh oleh kepala Desa Caluk yaitu Bapak Sutonowo. Adapun dalam pelaksanaannya kelompok ibu-ibu PKK sekaligus para bapak-bapak dusun Gupit menjadi partisipator yang langsung mempraktekan sistem tanam buah dalam pot atau tabulampot. Bahkan salah satu warga, yakni Bapak Suyono langsung membuat 33 cangkok buah jambu biji merah untuk ditanam di dalam pot. Selain bapak Suyono, dari kelompok ibu-ibu PKK yakni ibu Uci dan Ibu Aning mengatakan bahwa sebelum mengenal tabulampot mereka hanya asal menanam tanaman, sehingga hasil buahnya juga tidak maksimal. Mereka pernah menanam cabe, namun tanaman tersebut tidak membuahkan hasil. Maka, dengan bekal dari hasil pendampingan tabulampot ini maka minat untuk bercocok tanam dari para ibu-ibu desa Caluk meningkat kembali.

Demikian juga dengan bapak Supangat (selaku ketua RT 01), dengan pendampingan ini beliau sangat sadar akan pemanfaatan ladang pertanian di musim kemarau untuk menghasilkan perekonomian yang tinggi. Dengan mayoritas warga yang bekerja sebagai petani ditunjang oleh lahan yang tandus, ini maenjadi asset yang bisa digali potensinya dengan sistem tanam yang tepat. Sehingga meskipun terjadi musim kemarau mereka tetap mampu menciptakan perekonomian yang stabil. Karena buah hasil dari sistem tanam tabulampot bisa dijual saat waktu panen tiba. Panen tersebut tidak terpengaruh oleh perubahan musim.

Senada dengan hal di atas, bapak Mujiono selaku tokoh agama Katholik yang juga menjabat sebagai kepala dusun Gupit berharap masyarakat dusun Gupit mulai menyadari pentingnya melakukan penghijauan di sekitar rumah. Menurut bapak Mujiono, tabulampot ini sangat bermanfaat bagi masyarakat Dusun Gupit yang memiliki keadaan geografis yang gersang. Dan diharapkan kegiatan menanam buah (khususnya jambu biji) di dalam pot ini bisa terus berkembang dan dapat memenuhi 
kebutuhan buah masyarakat Dusun Gupit. Dan nantinya bisa dijadikan sumber pendapatan tambahan bagi masyarakat dusun setempat. Selain itu, dengan pengembangan Tabulampot ini diharapkan dapat menjadikan Dusun Gupit ini menjadi semakin asri dan sejuk.

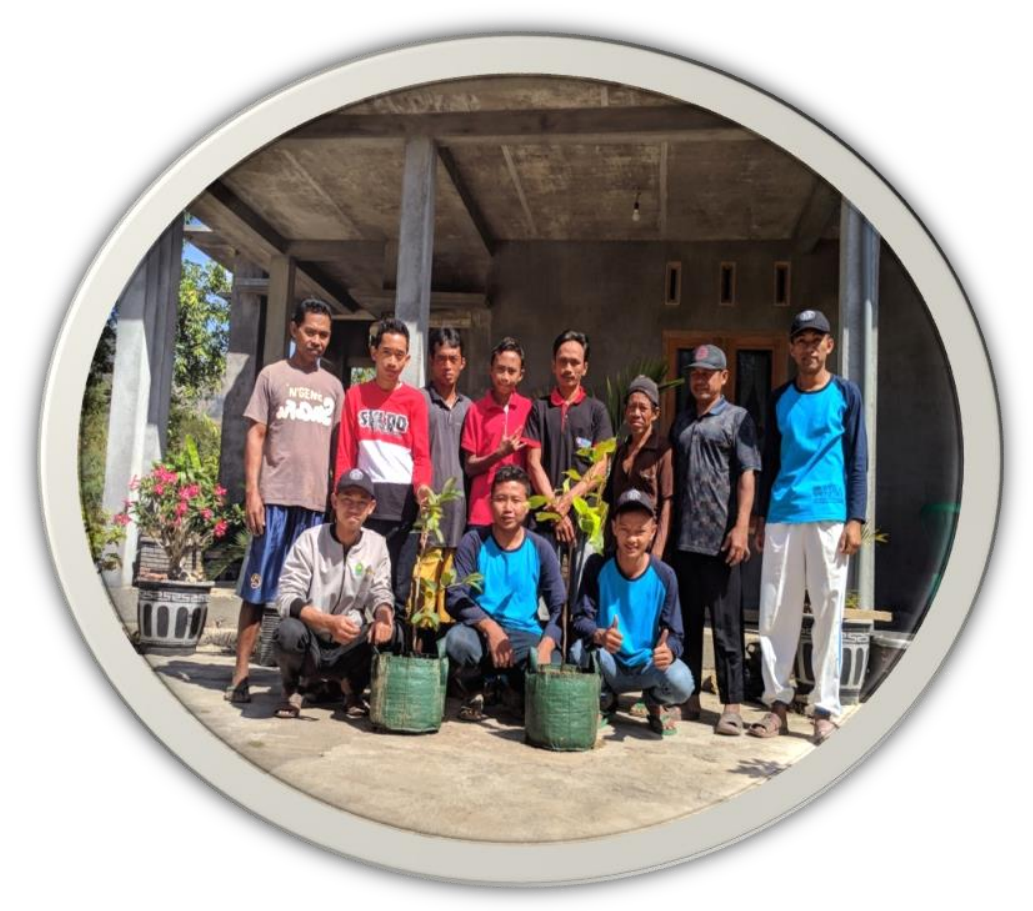

Gambar 3. Tabulampot hasil cangkok dengan media pupuk. (foto Bersama setelah pelatihan tabulampot).

\section{KESIMPULAN}

Agar kegiatan-kegiatan hasil pendampingan pembuatan tanaman dalam pot atau tabulampot tetap berjalan setelah masa pendampingan selesai, maka dibutuhkan tindak lanjut yang berkesinambungan. Monitoring dilakukan mulai dari tahap pencangkokan bibit tanaman, perawatan tanaman, hingga pada saat tanaman dapat dipanen dan dapat menghasilkan secara ekonomi. Jika sebelumnya mereka memanen dan menjual ketela pada musim kemarau, maka dengan tambahan variasi tanaman dengan system tabulapot ini mereka tidak hanya dapat menjual ketela tetapi saja, tetapi juga bisa menjual buah-buahan seperti jambu biji merah dan jambu kristal sehingga menjadi tambahan secara ekonomi. Apalagi jenis jambu yang ditanam adalah jambu yang produktif. Kedepannya, diharapkan program tanam buah dalam pot ini menjadi salah satu aset yang dapat diandalkan oleh masyarakat untuk 
menambah pendapatan, terutama menyadari kondisi tanah yang di Caluk tandus sehingga program ini menjadi alternatif yang tepat untuk saat ini. Untuk jangka Panjang program ini diharapkan akan meningkatkan perekonomian masyarakat Desa Caluk, baik ibu-ibu PKK atau ibu-ibu rumah tangga, bapak-bapak, para pemuda, dan masyarakat Desa Caluk pada umumnya.

\section{DAFTAR PUSTAKA}

Lembaga Penelitian dan Pengabdian kepada Masyarakat (LPPM) IAIN Ponorogo. (2019). Panduan KPM ABCD IAIN Ponorogo. Ponorogo: Lembaga Penelitian dan Pengabdian kepada Masyarakat (LPPM) IAIN Ponorogo.

Pedoman KKN Tematik Posdaya Berbasis ABCD Angkatan 67. (2017). Universitas Islam Negeri Raden Fatah Palembang, LP2M UIN Palembang.

Pedoman Kuliah Pengabdian Masyarakat (KPM) Pos pemberdayaan Keluarga (Posdaya) Berbasis Masjid. (2017). LPPM IAIN Ponorogo.

Karlina, Eli, Muhammad Arif, dan Sodikin. (2017). "Pengaruh Bekerja di Luar Negeri terhadap Tingkat Ekonomi dan Perceraian," Sosio Didaktika, Vol. 4, no. 1.

https://rumahtanaman.com/tabulampot-tanaman-buah-dalam-pot/ "Panduan Lengkap Cara Menanam TABULAMPOT (Tanaman Buah Dalam Pot) yang RAJIN Berbuah"( 2021, Januari 15).

Rahmah, Novita Awalia, https://paktanidigital.com/artikel/panduan-mudahcangkok-jambu-biji-bagi-pemula/"Panduan Mudah Cangkok Jambu Biji Bagi Pemula" (2020, Maret 20). 